\title{
Laboratory assessment of molluscicidal and cercariacidal effects of Glinus lotoides fruits
}

\author{
Gebrehiwot Kiros $^{1}$, Berhanu Erko ${ }^{2}$, Mirutse Giday ${ }^{2^{*}}$ and Yalemtsehay Mekonnen ${ }^{3}$
}

\begin{abstract}
Background: The negative impact of synthetic molluscicides on the environment and their high cost necessitated search for an alternative approach of using plant extracts for the control of schistosomiasis. The objective of this study was, therefore, to evaluate aqueous and ethyl acetate crude extracts of Glinus lotoides fruits for their cercariacidal activity and molluscicidal effect against schistosome snail intermediate hosts.

Methods: Assessment of the molluscicidal activity against Biomphalaria pfeifferi was made by immersion method in accordance with WHO guideline. The results of mortality were statistically analyzed using probit analysis. The attenuating effect of the plant on Schistosoma mansoni cercariae was determined using establishment of adult worms as a parasitological parameter post exposure.

Results: The 24 and 48 hour- $L C_{50}$ values for the aqueous extract of $G$. lotoides fruits were 47.1 and $44.1 \mathrm{mg} / \mathrm{L}$, respectively, whereas that of ethyl acetate were 66.1 and $59.6 \mathrm{mg} / \mathrm{L}$, respectively. The 24 and 48 hour $\mathrm{LC}_{90}$ values for the aqueous extract of $G$. lotoides fruits were 56.96 and $51.0 \mathrm{mg} / \mathrm{L}$, respectively, while that of ethyl acetate were 77.2 and $70.0 \mathrm{mg} / \mathrm{L}$, respectively. The in vitro cercariacidal activity was determined after $2 \mathrm{hrs}$ of exposure to the aqueous plant extract. It was found out that the $\mathrm{LC}_{50}$ and $L C_{90}$ values were 18.7 and $41.7 \mathrm{mg} / \mathrm{L}$, respectively. Besides, infectivity of Schistosoma mansoni cercariae to mice was determined by exposing mice to cercariae pre-treated with the sub-lethal concentrations $(3.7,11.6$ and $18.7 \mathrm{mg} / \mathrm{L})$ of the aqueous extract. A significant reduction in worm burden in mice was obtained at $11.6 \mathrm{mg} / \mathrm{L}(\mathrm{p}<0.05)$. Moreover, the reduction in number of worms recovered was highly significant at $18.7 \mathrm{mg} / \mathrm{L}(p<0.001)$.
\end{abstract}

Conclusions: The results showed that G. lotoides has molluscicidal activity against B. pfeifferi snails and cercariacidal activity against S. mansoni. Yet, further comprehensive evaluation is recommended for the possible use of G. lotoides against $B$. pfeifferi and the schistosome parasite.

Keywords: Glinus lotoides, Molluscicide, Cercariacide, Schistosomiasis, Ethiopia

\section{Background}

Schistosomiasis is a parasitic disease caused by blood-flukes of the genus Schistosoma. People get infected by having contact with freshwater that harbors free-swimming larval forms of the parasite shed from freshwater snail intermediate hosts [1,2]. Globally, about 200 million people are infected with schistosomes and about 600 million are at risk [3]. Schistosome infection is the second parasitic infection after malaria as a cause of morbidity and mortality $[4,5]$.

\footnotetext{
* Correspondence: mirutseg@yahoo.com

${ }^{2}$ Aklilu Lemma Institute of Pathobiology, Addis Ababa University, P.O. Box 1176, Addis Ababa, Ethiopia

Full list of author information is available at the end of the article
}

In Ethiopia, two forms of human schistosomiasis have been known to be endemic. Intestinal schistosomiasis is caused by Schistosoma mansoni and is transmitted by Biomphalaria snails whereas urinary schistosomiasis is caused by Schistosoma haematobium and is transmitted by bulinid snails [6]. It is estimated that four million people are affected by schistosomiasis and 29.89 million people are placed at risk of infection [7].

Although effective, safe, and inexpensive single-dose praziquantel is available to treat schistosomiasis with the prime objective of morbidity control [4], sustainable control of schistosomiasis requires integrated approach including repeated mass chemotherapy using praziquantel,

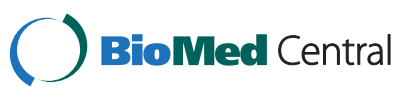


public health education focusing on behaviour changes towards risk factors, improving sanitation, provision of clean water supply, and snail control [8]. Since there is a possibility of re-infection even after repeated mass chemotherapy with praziquantel [9], complementing chemotherapy with measures such as snail control is necessary to prevent re-infection of people in endemic areas.

Snail control through the use of synthetic molluscicides forms an important part in the integrated schistosomiasis control programme [10]. However, the high cost of synthetic compounds such as Bayluscide ${ }^{\bullet}$ (Bayer, Leverkusen, Bayerwerk, Germany) and their negative impact on the environment have stimulated interest in search for alternative molluscicides of plant origin [11]. Many plant species have been proved to have molluscicidal properties against different snail species. The most potent plant that has been known to have molluscicidal activity against snail intermediate hosts of schistosome is Phytolacca dodecandra [12]. Alternanthera sesselis [13], Balanites aegyptiaca [14] and Jatropha curcas [15] also lie among plants with molluscicidal activities.

Glinus lotoides, a plant indigenous to Ethiopia, has a variety of traditional medicinal uses including the treatment of tapeworm infestation and other intestinal parasites, using as anti-fungal agent and for relieving of inflammation, and also as a remedy for diarrhea. Four triterpinoid saponins and flavonoides have been isolated from the seeds of G. lotoides grown in Ethiopia [16]. Pharmacological studies on G. lotoides seeds showed in vitro taenicidal activity against Taenia saginata [17] and the in vitro and in vivo taenicidal activity against Hymenolopis nana $[18,19]$. The methanol extract of $G$. lotoides seeds of the plant also possess antimicrobial activity [20]. Besides, the hydro-alcoholic seed extract of the plant was also reported to have anti-cancer activity. However, no work has been reported so far on the molluscicidal and cercariacidal activity of G. lotoides in Ethiopia. This study, therefore, aimed to evaluating the aqueous and ethyl acetate extracts of G. lotoides fruits for their molluscicidal and cercariacidal activities.

\section{Methods}

\section{Plant material collection}

Fresh fruits of G. lotoides were collected from its natural habitat around Koka Water Reservoir, located at $90 \mathrm{~km}$ southeast of Addis Ababa, in Oromia Regional State, Ethiopia. Fruits were then transported to laboratory in a sack to avoid direct sunlight. Identity of the plant was confirmed by the third author at Aklilu Lemma Institute of Pathobiology, Addis Ababa University (AAU) and a voucher specimen (Kiros 001) was deposited at the National Herbarium, College of Natural Sciences, Addis Ababa University, Ethiopia.

\section{Preparation and extraction of the plant material}

The fruits of G. lotoides were washed using tap water, and air dried at room temperature $\left(25-27^{\circ} \mathrm{C}\right)$ for two weeks. After drying, the fruits were ground into powder with the help of pestle and mortar. Powder was sieved using a mesh of 250 microns to get fine material. The powder was then kept in a screw caped glass container until extraction [21]. Extraction of the fine powdered material was made using two solvents; water and ethyl acetate. Aqueous extract was prepared by soaking $1 \mathrm{~g}$ of the dried plant powder in $300 \mathrm{ml}$ of aged water and shaking it for 24 hours at $160 \mathrm{rpm}$ at room temperature $\left(25^{\circ} \mathrm{C}\right)$. After shaking, the unfiltered suspension was directly used to prepare a stock solution. Ethyl acetate extract on the other hand was prepared by soaking $10 \mathrm{~g}$ of the dried fruits powder in $250 \mathrm{ml}$ of ethyl acetate. The solution was extracted by shaking it for 72 hours at $160 \mathrm{rpm}$ at room temperature. The extracted material was then concentrated to dryness under reduced pressure using Rota vapor at $45^{\circ} \mathrm{C}$. The crude extract obtained was then refrigerated at $-20^{\circ} \mathrm{C}$ until bioassay $[14,22]$.

\section{Preparation of the stock solution and serial dilution}

For aqueous extract, the plant material soaked for 24 hours was directly used to prepare the stock solution by adjusting it to $1000 \mathrm{ml}$ using aged water. For the ethyl acetate extract, stock solution was prepared by dissolving $1 \mathrm{~g}$ up to $1000 \mathrm{mg} / \mathrm{L}$ concentration by adding a suitable volume of aged water. For each extract, further serial dilutions to which snails were exposed were made from the stock solution. Once the extent of the toxicity range was determined, several convenient concentrations of the stock solution were prepared to give mortalities between 0 to $100 \%$. Serial dilutions for water extract were prepared to a final concentration of $0.0,40,42.5,45,47.5,50,52.5$, $55,57.5$ and $60 \mathrm{mg} / \mathrm{L}$. Similarly, the final concentrations for ethyl acetate extract were 0.0, 57.5, 60, 62.5, 65, 67.5, $70,72.5,75,77.5$ and $80 \mathrm{mg} / \mathrm{L}$. In both cases, the series of concentrations were prepared in a final volume of $250 \mathrm{ml}$ aged water. These concentrations were prepared by taking the calculated volume from the stock solution and then diluted with aged water until1000 $\mathrm{ml}[22,23]$.

\section{Molluscicidal potency test of the plant extracts}

The snail species used in this study was Biomphalaria pfeifferi. The snails were collected from their natural habitats, in small streams of Sheno and Chacha, which are located at 80 and $100 \mathrm{~km}$ North of Addis Ababa, respectively. Uniform sized $(8-12 \mathrm{~mm})$ snails were collected using dip-net scoop and were brought to Aklilu Lemma Institute of Pathobiology (ALIPB) laboratory using open plastic buckets which contained some sand, vegetation and water. Snails were cleaned from debris attached to them and screened for any trematode 
infection according to Christensen and Frandsen [24]. The molluscicidal potency test of G. lotoides crude extract against $B$. pfeifferi was performed according to established procedure [25]. A total of 10 snails were exposed per test to different concentrations of aqueous $(37.5-60 \mathrm{mg} / \mathrm{L})$ and ethyl acetate (55-80 mg/L) extracts. Snails were exposed to the extract for 24 hours under room temperature (25$27^{\circ} \mathrm{C}$ ). After 24 hours, snails were removed from the container and were transferred to a new recipient filled with aged water. The snails then remained under observation for another 24 hours. A group of ten snails were kept in aged water under the same experimental conditions as a negative control group. The experiment for each concentration was repeated three times. The snails were not fed during the course of the experiment. It had been observed that healthy snails live up to 5 days or more without food, provided other environmental conditions are constant [10]. Mortality rate was recorded after every 24 hours up to 48 hours. Toxicity was expressed as $\mathrm{LC}_{50}$ and $\mathrm{LC}_{90}$ corresponding to concentrations that killed $50 \%$ and $90 \%$ of the tested snails, respectively. The $\mathrm{LC}_{50}$ and $\mathrm{LC}_{90}$ values were determined for both 24 and 48 hours exposure [26,27]. Snails were considered dead if they did not move and were either retracted well into or hanging out of the shell, with discolored body. Mortality was also assessed by probing the snails with a blunt wooden probe to elicit typical withdrawal movements.

\section{Mice infectivity of Schistosoma mansoni cercariae pretreated with sublethal concentrations of Glinus lotoides fruit aqueous extract}

Establishment of adult worms 48 days post-exposure was used as a parasitological parameter to measure the attenuating effect of the plant on $S$. mansoni cercariae. Infectivity of $S$. mansoni cercariae to mice was determined by pre-exposing the cercariae to sublethal concentrations. Cercarial sublethal concentrations $\left(\mathrm{LC}_{15}\right.$, $\mathrm{LC}_{35}$ and $\mathrm{LC}_{50}$ ) were determined using probit analysis computer software programme. These were found to be 3.7, 11.6 and $18.7 \mathrm{mg} / \mathrm{L}$. Aqueous extract of G. lotoides fruit was adjusted to stock solution of $1000 \mathrm{mg} / \mathrm{ml}$ by aged water. A series of concentrations containing 3.7, 11.6 and $18.7 \mathrm{mg} / \mathrm{L}$ were prepared from the stock solution. Five test tubes were prepared for every concentration. One hundred fifty cercariae (the pre-determined infective dose) were transferred using micro-pipette into each test tube. The cercariae were then exposed to these concentrations for $2 \mathrm{~h}$ at room temperature before being used to infect mice. Five mice of both sexes with the age of 5-7 weeks were individually exposed for every concentration for 1 hour using the tail immersion method in a total volume of $10 \mathrm{ml}$ of cercarial suspension [28]. Mice were washed to remove cercariae that may remain in hairs. Then, the numbers of cercariae left in the test tubes were counted, and the cercariae to which the mice exposed were determined.

Each mouse was exposed to $128 \pm 10$ cercariae. After 2 hour exposure to the fruit extract, mice were maintained under standard condition in the animal house. As a control, five mice were individually exposed to the same number of cercariae untreated to the fruit extract. At 45 days post infection, fecal samples for each mouse was collected and checked for schistosome eggs using KatoKatz smear. At 48 days post infection, all mice were dissected. Worms were recovered from liver and intestine by perfusion using saline solution. Number of worms recovered was counted for both experimental and control groups. Then worm load per mouse was determined as described by $\mathrm{Al}-$ Zanbagi and Abuljadayel [29] and Kamel et al. [30]. Percentage reduction in worm burden resulting from the plant extract was also calculated using the following formula as described by Metwally [31]. $\mathrm{P}=(\mathrm{C}-\mathrm{V}) / \mathrm{C}$ $\mathrm{X} 100$; where: $\mathrm{P}=\%$ reduction in worm burden, $\mathrm{V}=$ mean number of worms recovered from mice infected with pretreated cercariae (experimental), $\mathrm{C}=$ mean number of worms recovered from mice infected with untreated cercariae (infected control).

\section{Cercariacidal potency test of the aqueous extract of Glinus lotoides fruits \\ Preparation of cercarial suspension}

Infected B. pfeifferi snails were collected from Bishan Gari, which is located at $235 \mathrm{~km}$ southeast of Addis Ababa. Snails were individually placed in a Petri dish containing $5 \mathrm{ml}$ of water followed by exposure to artificial light for 2 hours. Emerging cercariae were observed under dissecting microscope. The cercariae shed by the snails were then pooled into a glass beaker and mixed well to have uniform distribution. The number of cercariae in $200 \mu \mathrm{l}$ was counted under microscope using replicated samples. The volume of water to get 150 cercariae was then estimated. This was used for the in vivo test. For the in vitro test, the cercariae in $100 \mu \mathrm{l}$ were counted using replicated samples and the average was used.

\section{In vitro cercariacidal activity test of the aqueous extract of Glinus lotoides fruits}

A series of concentrations containing 5, 10, 20, 40 and $55 \mathrm{mg} / \mathrm{L}$ were prepared in a Petri dish. An average of twenty freshly shed cercariae were transferred into each Petri dish using micro-pipette. The same number of cercariae was placed in Petri dishes containing aged water as a control group. Each dilution, as well as control group, was tested in duplicate. The cercariae were observed under a dissecting microscope for survival and mortality at a successive interval of 30 minutes, 1 hour, 1 and half hours and 2 hours. They were considered to be dead when 
they stopped movement, sank down and detached their tail [27]. At the end of each experiment, iodine was added for clarity in counting of the total number of cercariae as a confirmation of accuracy of the counting procedure. The $\mathrm{LC}_{50}$ and $\mathrm{LC}_{90}$ values of aqueous extract of $G$. lotoides fruits on Schistosoma mansoni cercariae after 2 hour exposure were determined [15].

\section{Statistical analysis}

The $\mathrm{LC}_{50}$ and $\mathrm{LC}_{90}$ were determined by probit analysis using SPSS version 20 with 95\% confidence limit. Number of adult worms recovered from mice was represented as mean \pm SD of the mean. Data was subjected to ANOVA to determine the significant difference in worm burden between the experimental and control mice [32]. A p-value of $<0.05$ was set as statistically significant.

\section{Results}

Aqueous and ethyl acetate extracts of G. lotoides fruits showed activities against B. pfeifferi and S. mansoni cercariae. The extracts caused concentration dependent mortality of B. pfeifferi from 0 - 100\% mortality in concentrations of $37.5-80 \mathrm{mg} / \mathrm{L}$. The 24 and 48 -hour- $\mathrm{LC}_{50}$ and $\mathrm{LC}_{90}$ values of aqueous extract of G. lotoides fruit were higher than that of ethyl acetate (Table 1).

In vitro cercariacidal activity test for the aqueous extract of G. lotoides fruits showed that the plant possessed cercariacidal activity against $S$. mansoni cercariae. The mortality was both time and concentration dependent. At the first 30 minutes of exposure to $5 \mathrm{mg} / \mathrm{L}$, no mortality of S. mansoni cercariae was observed. However, after 2 hour exposure, mortality at the same concentration was elevated to $20 \%$. The $\mathrm{LC}_{50}$ and $\mathrm{LC}_{90}$ values were determined after 2 hours exposure to the plant extract (Table 2).

Infectivity of $S$. mansoni cercariae to mice was significantly reduced $(\mathrm{P}<0.05)$ by exposing mice to cercariae pre treated with the sub lethal concentrations of the aqueous extract. Pre-exposure of the cercariae to 3.7, 11.6 and $18.7 \mathrm{mg} / \mathrm{L}$ reduced the establishment of adult worms in the liver and intestine by $35.3 \%, 55.9 \%$ and
$91.2 \%$, respectively (Table 3 ). Comparison of the mean worm burden per mouse for each group using one way ANOVA showed that there was no statistically significant difference between mice infected with untreated cercariae and mice infected with cercariae pre-exposed to the lower concentration, $3.7 \mathrm{mg} / \mathrm{L}(\mathrm{P}>0.05)$. In contrast, significant difference was obtained in mice exposed to cercariae pre-treated with $11.6 \mathrm{mg} / \mathrm{L}(\mathrm{P}<0.05)$. Moreover, pre-exposure of the cercariae to the highest concentration almost inhibits the establishment of adult worms, which was highly significant $(\mathrm{P}<0.001)$. At this concentration, the infectivity of the cercariae and their subsequent development into adult worms was highly suppressed with worm recovery reduced from 6.8 worms/mouse in the control group to 0.6 worm/mouse at the highest concentration.

\section{Discussion}

The results of the present study revealed that Biomphalaria pfeifferi was susceptible to the fruits of G. lotoides extracts at different concentrations. The $\mathrm{LC}_{50}$ and $\mathrm{LC}_{90}$ values for the aqueous extract after 24 hours exposure were 47.1 and $56.96 \mathrm{mg} / \mathrm{L}$, respectively. The $\mathrm{LC}_{50}$ and $\mathrm{LC}_{90}$ of the same extract after 48 hours exposure were 44.1 and $51 \mathrm{mg} / \mathrm{L}$, respectively. The $\mathrm{LC}_{50}$ and $\mathrm{LC}_{90}$ for the ethyl acetate extract after 24 hour exposure were 66.1 and $77.2 \mathrm{mg} / \mathrm{L}$, respectively. However, after 48 hours exposure, the extract produced $\mathrm{LC}_{50}$ and $\mathrm{LC}_{90}$ of 59.6 and $70 \mathrm{mg} / \mathrm{L}$ respectively. The potency of $G$. lotoides aqueous extract on B. pfeifferi in the present study was much higher when compared to other related plant extracts used in other work. Diallo et al. [33] reported that the aqueous extract of Glinus oppositifolius showed 100\% mortality of B. Pfeifferi only at $200 \mathrm{mg} / \mathrm{L}$.

The continuous crawling out from the test extract solution of snails exposed to sub lethal concentration is taken as an irritative and avoidance behavior as described by Evans et al. [34] and Brackenbury [35] for bulinid snails. The ability of the snails to crawl out of the test extract solution and then aggregate at the water-air interface in snails exposed to sub-lethal concentration, where their body is

Table 1 The molluscicidal effect of aqueous and Ethyl acetate extracts of Glinus lotoides fruits against Biomphalaria pfeifferi

\begin{tabular}{|c|c|c|c|c|}
\hline \multirow[t]{2}{*}{ Exposure period } & \multirow[t]{2}{*}{ Plant product } & \multicolumn{2}{|c|}{ Lethal concentration $(\mathrm{mg} / \mathrm{l})$ or $\mathrm{mg} / \mathrm{L}$} & \multirow[t]{2}{*}{ Negative control (\% mortality) } \\
\hline & & $\mathrm{LC}_{50}$ & $\mathrm{LC}_{90}$ & \\
\hline \multirow[t]{2}{*}{24 hour } & aqueous extract & $\begin{array}{c}47.1 \\
\mathrm{Cl}(44.6-49.6)\end{array}$ & $\begin{array}{c}56.96 \\
\text { Cl (53.9-62.6) }\end{array}$ & 0 \\
\hline & Ethyl acetate extract & $\begin{array}{c}66.1 \\
\mathrm{Cl}(66.52-68.51)\end{array}$ & $\begin{array}{c}77.2 \\
\mathrm{Cl}(73.8-83.2)\end{array}$ & \\
\hline \multirow[t]{2}{*}{48 hour } & aqueous extract & $\begin{array}{c}44.1 \\
\mathrm{Cl}(41.9-55.9)\end{array}$ & $\begin{array}{c}51 \\
\mathrm{Cl}(48.8-54.9)\end{array}$ & 0 \\
\hline & Ethyl acetate extract & $\begin{array}{c}59.6 \\
\mathrm{Cl}(55.8-62.1)\end{array}$ & $\begin{array}{c}70 \\
(67.1-77.2)\end{array}$ & \\
\hline
\end{tabular}


Table 2 In vitro cercariacidal effect of aqueous extract of Glinus lotoides fruits

\begin{tabular}{lcccc}
\hline $\begin{array}{l}\text { Exposure } \\
\text { period }\end{array}$ & $\begin{array}{c}\text { Plant } \\
\text { product }\end{array}$ & \multicolumn{2}{c}{$\begin{array}{c}\text { Lethal concentrations } \\
(\mathbf{m g} / \mathbf{l}) \text { or } \mathbf{~ m g} / \mathbf{L}\end{array}$} & \multirow{2}{*}{$\begin{array}{c}\text { Negative control } \\
\text { (\% mortality) }\end{array}$} \\
\cline { 3 - 4 } & & $\mathrm{LC}_{\mathbf{5 0}}$ & $\mathbf{L C}_{\mathbf{9 0}}$ & \\
\hline $\mathbf{2}$ hour & $\begin{array}{c}\text { Aqueous } \\
\text { extract }\end{array}$ & $\begin{array}{c}18.7 \\
\mathrm{Cl}(14.8-22.5)\end{array}$ & $\begin{array}{c}41.7 \\
\mathrm{Cl}(35.998-50.50)\end{array}$ & 0 \\
\hline
\end{tabular}

not in close and continuous contact to the plant extract, is similar to observation described by Adetunji and Salawu [10]. Azare et al. [13] also observed movement of snails to the side of the container in an attempt to escape from the test media containing Althernanthera sessils treated water. The mechanism of $B$. pfeifferi partially leaving the treated water has been found to increase the survival of B. straminae exposed to sub lethal doses of niclosamide [36] and B. glabrata exposed to Phytolacca dodecandra [37].

Phytochemical studies of plants reported for their molluscicidal activities in different countries revealed the presence of saponins, alkaloids and flavonoides [38,39]. Saponins are also one of the major classes of compounds that possess molluscicidal activity. Phytolacca dodecandra, one of the potent molluscicidal plants, has saponins. Endale et al. [16] demonstrated that the seeds of G. lotoides contain saponins and flavonoides.

As it was evident from the $\mathrm{LC}_{50}$ and $\mathrm{LC}_{90}$ values of the 24 and 48 hours exposure, the molluscicidal potency of the aqueous extract was higher than that of the ethyl acetate. This variation in activity might be attributed to the fact that the saponins and flavonoides responsible for its activity are extracted in greater measures with more polar solvent such as water than with less polar solvents such as ethyl acetate. This finding corroborated other studies that reported differences in the activities of extracts obtained from the same plant part using different solvents. For instance, the aqueous extract of Nerium indicum is more potent than the N-butanol extract of the same plant [40].

For a plant to be considered as a candidate molluscicide, a crude preparation of its parts should be active at $100 \mathrm{mg} / \mathrm{L}$ or less and kill $90 \%$ of snails exposed for $24 \mathrm{~h}$
$[25,41]$. In the present study, aqueous extract of $G$. lotoides fruit was active at a concentration as low as $56.96 \mathrm{mg} / \mathrm{L}$ and killed $90 \%$ of the snails within 24 hour contact to the plant extract. Thus, G. lotoides fruit aqueous extract can be considered as a candidate molluscicide. On the other hand, the alcoholic or lipophilic plant extract is considered as a candidate molluscicide if it has $\mathrm{LC}_{90}$ values equal or less than $20 \mathrm{mg} / \mathrm{l}$ after 24 hours. In the present study, ethyl acetate extract of G. lotoides fruit showed $\mathrm{LC}_{90}$ value of $70 \mathrm{mg} / \mathrm{L}$ after 24 exposures to the ethyl acetate extract. Therefore, according to this criterion, ethyl acetate extract may not be considered as a candidate molluscicide.

The present observation showed that aqueous extract of G.lotoides fruits possess cercariacidal activity against S. mansoni cercariae. The activity was both time and dose dependent. This result is similar to that of Mohamed et al. [42] who reported the cercariacidal activity of the crushed seed of Nigella sativa to be both time and concentration dependent. This finding is also in line with the reported data for Milletia thoningii by Perret et al. [43] and Irish germanica by Singaba et al. [23] who reported the timeconcentration relationship of the plants extracts. Other studies by Rug and Rupel [15] using different solvent extracts of Jatropha curcas and by Ahmed and Ramzy [44] using aqueous extract of Solanum nigrum also reported similar findings.

Aqueous extract of G. lotoides fruits were significantly reduced the infectivity of $S$. mansoni cercariae on mice. At lower concentration $(3.7 \mathrm{mg} / \mathrm{L})$ the worm load per mouse was decreased by $35.3 \%$ compared with control group, while at the highest concentration $(18.7 \mathrm{mg} / \mathrm{L})$, this was reduced by $91.2 \%$. According to the present results, the plant was effective in this respect at the highest concentration, $18.7 \mathrm{mg} / \mathrm{L}$. The decrease in worm load/ mouse could be due to the attenuation of cercarial mobility and activity to be unable to penetrate the mice skin during exposure to such cercariae [30].

G. lotoides is an indigenous plant grown in Ethiopia. It is traditionally known for the treatment of tape worm infestation and other intestinal worms [45-47], diarrhea,

Table 3 Percentage reduction of worm burden in mice infected with cercariae pre-treated with aqueous extract of $G$. lotoides fruits

\begin{tabular}{|c|c|c|c|c|c|}
\hline \multicolumn{6}{|c|}{ Worm burden (Mean \pm SD) } \\
\hline \multirow[t]{2}{*}{ Treatments } & Male & Female & Couple & Total & \multirow{2}{*}{$\begin{array}{c}\text { Total worm } \\
\text { burden reduction (\%) }\end{array}$} \\
\hline & $\mathrm{M} \pm \mathrm{SD}$ & $M \pm S D$ & $\mathrm{M} \pm \mathrm{SD}$ & $\mathrm{M} \pm \mathrm{SD}$ & \\
\hline Infected control & $2.4 \pm 0.418$ & $3.2 \pm 0.636$ & $1.2 \pm 0.398$ & $6.8 \pm 0.398$ & - \\
\hline $3.7 \mathrm{mg} / \mathrm{L}$ & $1.4 \pm 0.328$ & $2.2 \pm 0.48$ & $0.8 \pm 0.35$ & $4.4 \pm 0.5$ & $35.3 \%$ \\
\hline $11.6 \mathrm{mg} / \mathrm{L}$ & $1.8 \pm 0.79^{*}$ & $0.8 \pm 0.21^{*}$ & $0.4 \pm 0.17^{*}$ & $3 \pm 0.247^{*}$ & $55.9 \%$ \\
\hline $18.7 \mathrm{mg} / \mathrm{L}$ & $0.4 \pm 0.08^{* *}$ & $0.2 \pm 0.09^{* *}$ & $0.0 \pm 0.0^{* *}$ & $0.6 \pm 0.178^{* *}$ & $91.2 \%$ \\
\hline
\end{tabular}

Note Results are expressed as mean \pm SD of the mean of five observations. ${ }^{*}$ Indicates the level of significance of the experimental mice compared to the infected control. No statistical significant difference was obtained at $3.7 \mathrm{mg} / \mathrm{L}(P>0.05)$, * statistically significant at $11.6 \mathrm{mg} / \mathrm{L}(\mathrm{P}<0.05)$ and **highly significant difference at $18.7 \mathrm{mg} / \mathrm{L}(\mathrm{P}<0.001)$ compared with infected control. 
as a purgative as well as for curing boils and wounds [48]. In the current study, G. lotoides was proved to have molluscicidal and cercariacidal activity. Since its anthelminthic activities have been established [16], this new finding would widen the spectrum of its medicinal values.

\section{Conclusions}

From the present study, it can be concluded that aqueous and ethyl acetate crude extracts of G. lotoides fruits possess molluscicidal properties against the intermediate snail host, B. pfeifferi. Both extracts showed differing molluscicidal activity. $B$. pfeifferi was found to be more susceptible to the aqueous extract of $G$. lotoides fruits than to that of ethyl acetate. The aqueous extract also showed in vitro cercariacidal property against $S$. mansoni cercariae. Moreover, pre-treatment of $S$. mansoni cercariae with the aqueous extract of $G$. lotoides fruits before mice infection has produced a significant reduction of the infectivity of cercariae to mice. However, bioactivity guided fractionation to isolate the specific compound responsible for the molluscicidal as well as cercariacidal activity of the extracts is recommended.

\section{Competing interests}

The authors declare that they have no competing interests.

\section{Authors' contributions}

GK: wrote the first draft of the proposal, collected samples, conducted the experiment, analyzed the data and wrote the first draft of the manuscript. BE: come up with research idea, read and polished the proposal, participated in the collection of snail samples, supervised the conduct of the laboratory experiments, and participated in the write-up of the manuscript. MG: contributed to the development of the research idea, read and improved the proposal, collected and identified plant samples, supervised laboratory experiments and read and participated in the write up of the manuscript. YM: participated in the development of the proposal and writ-up of the manuscript. All authors read and approved the final manuscript.

\section{Acknowledgements}

We would like to express our sincere thanks to all staff members of research units of Medical Parasitology Endod and Other Medicinal Plants at Aklilu Lemma Institute of Pathobiology (ALIPB), Addis Ababa University for provision of laboratory facilities. We are also grateful to ALIPB staff Mr Sisay Dessie and Ms Bayissas Gebremedhin for their assistance during laboratory works and Dr Girmay Medhin for his help in statistical analysis. Last, but not least, we would like to thank Addis Ababa University, for the financial support to conduct the study.

\section{Author details}

${ }^{1}$ Wollo University, P.O. Box 1145, Dessie, Ethiopia. ${ }^{2}$ Aklilu Lemma Institute of Pathobiology, Addis Ababa University, P.O. Box 1176, Addis Ababa, Ethiopia. ${ }^{3}$ College of Natural and Computational Sciences, Microbial, Cellular and Molecular Biology Department, Addis Ababa University, P.O. Box 1176, Addis Ababa, Ethiopia.

Received: 12 August 2013 Accepted: 3 April 2014

Published: 8 April 2014

\section{References}

1. Naples J, Shiff C, Halden R: Reduction of infectivity of schistosome cercariae by application of cercariacidal oil to water. Am J Trop Med Hyg 2005, 73:956-961.
2. Mengistu M, Shimelis T, Torben W, Terefe A, Kassa T, Hailu A: Human intestinal schistosomiasis in communities living near three rivers of Jimma town, southwestern Ethiopia. Ethiop J Health Sci 2011, 21:111-118.

3. Ojewole JO: Indigenous Plant and schistosomiasis control in South Africa: molluscicidal activity of some Zulu Medicinal Plants. BLACPMA 2004, 3:1.

4. WHO: Prevention and Control of Schistosomiasis and Soil Transmitted Helminthiasis. Geneva: WHO Technical Report, Series No.912; 2002.

5. Domo DA, Kela SL: The efficacy of Maytenus senegalensis $(L)$ extracts on experimentally infected rats with S. mansoni. Int J Biomed HIth Sci 2009, 5:157-63.

6. Kloos H, Lo CT, Birrie H, Ayele T, Tedla S, Tsegay F: Schistosomiasis in Ethiopia. Soc Sci Med 1988, 26:803-827.

7. Chitsulo L, Engels D, Montresor A, Savioli A: The global status of schistosomiasis and its control. Acta Trop 2000, 77:41-51.

8. Mazigo HD, Nuwaha F, Kinung'hi SM, Morona D, Pinot De Moira A, Wilson S, Heukelbach J, Dunne DW: Epidemiology and control of human schistosomiasis in Tanzania. Parasites Vectors 2012, 28(5):274.

9. Hassan AA, Mahmoud AE, Hassan RA, Huseein EM: Evaluation of Euphorbia aphylla, Ziziphus Spina-Christi and Enterolobium Contortisiliquum as molluscicidal agents. J Am Sci 2011, 7:511-520.

10. Adetunji VO, Salawu OT: Efficacy of ethanolic leaf extracts of Carica papaya and Terminalia catappa as molluscicides against the snail intermediate hosts of schistosomiasis. J Med Plants Res 2010, 4:2348-2352.

11. Otarigho B, Morenikeji $O$ : Molluscicidal effects of aqueous and ethanolic extracts of Lemongrass (Cymbopogon citratus) leaf against the different developmental stages of Biomphalaria pfeifferi. NY Sci J 2012, 5:70-77.

12. Lemma A: Laboratory and field evaluation of the molluscicidal properties Phytolacca dodecandra (Endod). Bull WId HIth Org 1970, 42:597-612.

13. Azare AB, Okwute SK, Kela SL: Molluscicidal activity of crude water leaf extracts of Alternanthera sesselis on Bulinus (phy) globosus. Afr J Biotechnol 2007, 6:441-444.

14. Molla E: Molluscicidal and cercariacidal activity of Balanites aegyptica. MSC Thesis. Addis Ababa University; 2011

15. Rug M, Ruppel A: Toxic activities of the plant Jatropha curcas against intermediate snail hosts and larvae of schistosomes. Trop Med Int Hith 2000, 5:423-430.

16. Endale A, Wray A, Murill R, Schmidt PC, Merfor I: Hopane-Type Saponins from the Seeds of G. lotoides. Nat Prod 2005, 68:443-446.

17. Djote M: Taenicidal activity of Glinus lotiodes (Aizoaceae). J Ethiop Pharm Assoc 1978, 3:9-11.

18. Endale A, Getachew M, Gebre-Mariam T: In vitro taenicidal activity of the seeds of G. lotoides on Hymenolepis nana worms. Eth Pharm J 1997, 15:46-51.

19. Endale A, Kassa M, Gebre-Mariam T: In vivo anthelmintic activity of the extracts of Glinus lotoides in albino mice infested with Hymenolepis nana worms. Eth Pharm J 1998, 16:34-41.

20. Abdel-Hameed ES, El-Nahas HA, Abo-Sedera SA: Antischistosomal and antimicrobial activities of some Egyptian plant species. Pharm Biol 2008, 46:626-633.

21. Abdalla MA, El-Malik KH, Bayoumi RA: Application of some aqueous plant extracts as molluscicidal agents on Bulinus truncatus snails in Sudan. J Basic App/ Sci Res 2011, 1:108-117.

22. Salawu O, Odaibo A: The molluscicidal effects of Hyptis suaveolens on different stages of Bulinus globosus in the laboratory. Afr J Biotechnol 2011, 10:10241-10247.

23. Singaba AB, Ahmed AH, Sinkonenc J, Ovcharenkoc V, KaleviPihlajac K: Molluscicidal activity and new flavonoids from Egyptian Iris germanica L. (var. alba). Z Natur Forsch C 2006, 61:57-63.

24. Christensen NO, Frandsen A: An introduction to the taxonomy, morphology, biology and transmission ecology of species of the genus Schistosoma causing human African schistosomiasis. Denmark: Danish Bilharsiasis Laboratory; 1985.

25. WHO: Guidelines for evaluation of plant molluscicides. In Phytolacca dodecandra (Endod). Edited by Lemma A, Heyneman D, Silangwa S. Dublin: Tycooly International Publishing Limited; 1983:121-124.

26. Changbunjong J, Wongwit W, Leemingsawat S, Tongtokit $Y$, Deesin V: Effect of crude extract of Solanum xanthocarpum against snails and mosquito larvae. Southeast Asian J Trop Med Publ HIth 2010, 41:320-325

27. Eissa M, Bardicy S, Tadros T: Bioactivity of miltefosine against aquatic stages of Schistosoma mansoni, Schistosoma haematobium and their snail hosts, supported by scanning electron microscopy. Parasites \& Vectors 2011, 73:4-11. 
28. Oliver $L$, Stirewalt MA: An efficient method for exposure of mice to cercariae of Schistosoma mansoni. J Parasitol 1952, 1952(8):19-23.

29. Al-Zanbagi AA, Abuljadayel DA: Attenuation of Schistosoma mansoni larvae with a molluscicide derived from Euphorbia schimperiana. Scie J Al-Azhar Med Faculty Girls 2005, 26:1513-1524.

30. Kamel EG, El-Emam MA, Mahmoud SSM, Fouda FM, Bayaumy FE: Attenuation of Schistosoma mansoni cercarial infectivity to albino mice by methanol extract of some plant species. Pestic Biochem Physiol 2010, 98:342-348

31. Metwally NS: Potency of Allium sativum and Allium cepa oils against Schistosoma mansoni infection in mice. Egypt J Hosp Med 2006, 23:319-32.

32. Nahed HA, Riad HT, Mahmoud IY: Effects of garlic on albino mice experimentally infected with Schistosoma mansoni: A parasitological and ultra structural Study. Trop Bio Med 2009, 26:40-50.

33. Diallo D, Marston AM, Terreaux C, Toure Y, Paulsen BS, Hostettman K: Screening of Malian medicinal plants for antifungal, larvicidal, molluscicidal, antioxidant and radical scavenging activities. Phytother Res 2001, 15:401-406.

34. Evans NA, Whitfield PJ, Squire BJ, Fellows LE, Evans SV, Millott SM: Molluscicidal activity in the seeds of Millettia thonningii (Leguminosae: Papillionioidae). Trans R Soc Trop Med Hyg 1986, 80:451-453.

35. Brackenbury TD: Gross histopathological effects of an extract of Agave attenuate on the epithelium of the digestive tract of Bulinus africanus. Ann Trop Med Parasitol 1999, 93:519-526.

36. Sarquis O, Pieri OS, Dos Santos JAA: Effects of Bayluscide on the survival and water-leaving behaviour of $B$. straminea, snail host of schistosomiasis in Northeast Brazil. Mem Inst Oswaldo Cruz 1997, 92:511-518

37. Jurberg $P$, Barbosa $J V$, Rotenberg $L$ : The role of behaviour in survival of B. glabrata in bioassays with the plant molluscicide Phytolacca dodecandra. Mem Inst Oswaldo Cruz 1988, 83:41-46.

38. Singh KS, Yadav PR, Singh A: Molluscicides from some common medicinal plants of eastern Uttar Pradesh, India. J Appl Toxicol 2010, 30:1-7.

39. Larhsini M, Sebbane R, Kchakech H, Markouk M, Bekkouche K, Abbad A, El Abdounikhayari M, Sterner O: Screening of some Moroccan plant extracts for molluscicidal activity. Asian J Exp Bio/ Sci 2010, 1:964-967.

40. Wang H, Cai W, Wang W, Yang J: Molluscicidal activity of Nerium indicum mill, Pterocarya stenoptera and Rumex japonicum Houtt on Oncomelania hupensis. Biomed Envir Sci 2006, 19:245-248.

41. Mott KE: Plant Molluscicides, UNDP/World BankWHO. New York: John Wiley \& Sons Ltd.; 1987.

42. Mohamed AZ, Metwally NM, Mahmoud SS: Sativa seeds against Schistosoma mansoni different stages. Mem Inst Oswaldo Cruz 2005, 100:205-211.

43. Perrett $S$, Whitfield P, Bartlett A, Sanderson L: Attenuation of Schistosoma mansoni cercariae with a molluscicide derived from Millettia thonningii. Parasitology 1994, 109:559-63.

44. Ahmed AH, Ramzy RM: The molluscicidal and cercaricidal activities of the Egyptian weed, Solanum nigrum L. Ann Trop Med Parasitol 1997, 91:931-7.

45. Demma J, Gebre-Mariam T, Asres K, Ergetie W, Engidawork E: Toxicological study on Glinus lotoides: a traditionally used taenicidal herb in Ethiopia. J Ethenopharmacol 2007, 111:451-7.

46. Edwards S, Tadesse M, Demissew S, Hedberg I: Flora of Ethiopia and Eriteria, Volume 1. 2nd edition. Addis Ababa: Education Materials Production and Distribution Enterprise (EMPDA); 2000:234-237.

47. Qureshi R, Bhatti G, Memon RM: Ethnomedicinal uses of herbs from northern part of Nara desert, Pakistan. Park J Bot 2010, 42:839-851.

48. Hamed Al, Springuel I, EL Emary NA, Mitome H, Myaoka H, Yamada Y: Triterpinoidal saponin glycosides from Glinus lotoides var. dictamnoides. Phytochemistry 1996, 43:143-188.

doi:10.1186/1756-0500-7-220

Cite this article as: Kiros et al:: Laboratory assessment of molluscicidal and cercariacidal effects of Glinus lotoides fruits. BMC Research Notes 2014 7:220

\section{Submit your next manuscript to BioMed Central and take full advantage of:}

- Convenient online submission

- Thorough peer review

- No space constraints or color figure charges

- Immediate publication on acceptance

- Inclusion in PubMed, CAS, Scopus and Google Scholar

- Research which is freely available for redistribution

Submit your manuscript at www.biomedcentral.com/submit
C Biomed Central 